Reprinted with permission from: Weed Technology. 1997. 11:586-590.

Published and copyrighted by: Weed Science Society of America, http://www.wssa.net

\title{
Effects of simulated defoliation on leafy spurge (Euphorbia esula)-infested rangeland ${ }^{1}$
}

DONALD R. KIRBY, THOMAS P HANSON, KELLY D. KRABBENHOFT, and MATT M. KIRBY

Professor, Animal and Range Science Department, North Dakota State University, Fargo, ND 58105; NW District Director, North Central Research Extension Center, Minot, ND 58701; Res. Specialist and undergraduate student, Animal and Range Science Department, North Dakota State University, Fargo, ND 58105.

\begin{abstract}
:
The effect of annual defoliation on leafy spurge-infested rangeland was investigated over a 5-year period. Artificial defoliation was conducted once or twice annually at various phenological growth stages of leafy spurge to simulate grazing by herded Angora goats. Single defoliation treatments did not reduce total leafy spurge stem densities. Defoliation twice in a growing season for 4 consecutive years reduced total leafy spurge stem densities by $55 \%$ over nondefoliated controls. Grass foliar cover and yield increased in all defoliation treatments. Despite the increased grass yield on single defoliation treatments, cattle use would likely be limited in these treatments due to the high density of leafy spurge stems. Stem densities of leafy spurge in twice-defoliated treatments should not deter cattle from grazing these sites, thereby increasing the available forage supply. The data suggest that repeated grazing of leafy spurge-infested rangeland within a growing season would be required to reduce stem densities adequately and increase cattle use and production from these sites.
\end{abstract}

\section{Nomenclature:}

Leafy spurge, Euphorbia esula L. \#² EPHES; angora goats (Capra hircus); cattle (Bos taurus).

\footnotetext{
${ }^{1}$ Received for publication January 26, 1997, and in revised form April 28, 1997

${ }^{2}$ Letters following this symbol are a WSSA-approved computer code from Composite List of Weeds, Revised 1989 Available from WSSA.
} 


\section{Additional index words:}

Biological control, density, noxious weed.

\section{Introduction}

Leafy spurge is an introduced, perennial weed from Eurasia that is extremely persistent and competitive in grazed rangelands (Dunn 1979). It has been reported to be present in 26 states and six Canadian provinces and in North Dakota alone occupies approximately 0.5 million ha (North Dakota Department of Agriculture 1991). Once established, leafy spurge has been reported to decrease grass yields by up to $75 \%$ and reduce annual income from cattle sales by $\$ 8.6$ million in North Dakota (Leistritz et al. 1992; Thompson et al. 1990).

Leafy spurge has proven difficult to control. Herbicides have been the most successful method to combat leafy spurge, but eradication has not been possible (Lym and Messersmith 1985a; Lym and Messersmith 1990). Costs of herbicide treatment programs for large infestations on rangeland can approach \$200/ha and require repeated annual applications (Bangsund et al. 1996; Lym and Messersmith 1985a, 1985b). Herbicide treatment programs for leafy spurge often exceed the total land value and approximate eight to 10 times the annual cash rent value of the land (Bangsund et al. 1996; Lym and Moxness 1989). Additionally, herbicide use is not practical or desirable near water sources, rough terrain, and in sensitive environments such as woodlands.

Leafy spurge is an invasive rangeland plant species that employs avoidance and tolerance mechanisms to withstand stresses such as defoliation from grazing. Cattle, the predominant herbivore of rangelands, avoid leafy spurge due to its low palatability and aversive-inducing chemical compounds (Kingsbury 1964; Kronberg et al. 1993, 1995; Muller et al. 1990). The large root biomass, early growth habit, aggressive sprouting capability, and prolific seed production contribute to the plant's tolerance to control (Messersmith et al. 1985; Raju 1985; Selleck et al. 1962).

Long-term sheep (Ovus aries) and goat (Capra hircus) grazing has provided effective control of leafy spurge (Bowes and Thomas 1978; Helgeson and Longwell 1942; Johnson and Peake 1960; Lym et al. 1997; Sedivec et al. 1995). Walker et al. (1994) reported that goats may be the better biological control agent for leafy spurge, especially in areas where leafy spurge is less palatable to sheep. Hanson et al. (1994) found domestic goats to prefer leafy spurge and many shrub species while avoiding most grasses in diet selections in southeastern North Dakota. However, sheep or goat grazing does not eradicate leafy spurge but may contain and reduce infestations over time. Sheep or goats can provide additional farm income and be used to control large infestations or infestations in sensitive environments where herbicide use is limited (Lacey et al. 1984; Williams et al. 1996).

A long-term leafy spurge grazing management program using herded Angora goats was initiated in 1991 on the Sheyenne National Grasslands of the Custer National Forest,

Page 2 of 9 
Lisbon, ND. The Grasslands, approximately 35,000 ha, are heavily infested with leafy spurge, making a widespread grazing program desirable. However, the timing and defoliation frequency of infestations that would provide adequate leafy spurge control was unknown. A 5-year study was initiated with the objective of assessing the effects of various defoliation treatments on leafy spurge and associated herbaceous yields.

\section{Materials and Methods}

The study was conducted on the Sheyenne National Grasslands of the Custer National Forest in Ransom County, approximately $5 \mathrm{~km}$ west and $5 \mathrm{~km}$ north of McLeod, ND. The Grasslands, also known as the Sandhills, are part of the Sheyenne Delta of glacial Lake Agassiz. The Grasslands are noted for a diversity of plant species (Seiler and Barker 1985). Various cool- and warm-season grasses, sedges, forbs, shrubs, and trees are present. Heavy infestations of leafy spurge also occur within the study area. Leafy spurge expansion has been extensive on wooded areas of the Grasslands because many of these areas have not been treated with herbicides.

Average precipitation for the area is $50 \mathrm{~cm}$, with $65 \%$ received during May through September. Over the study period, growing season and annual precipitation received were $15 \%$ and $12 \%$ higher than the long-term average (Figure 1). The long-term average monthly temperatures for the grazing period of May through October range from $22 \mathrm{C}$ to 6 C.The soil was a Maddock Hecla loamy fine sands complex (Maddock = sandy, mixed, udorthentic Haploboroll; Hecla = sandy, mixed, Udic Haploboroll; with less than 3\% slope). The soils within the area were formed in wind-sorted fine sands. They are deep, excessively drained, and nearly level to hilly soils on low hummocks and hills. Permeability is rapid and the available water-holding capacity is low. Soils are too sandy for cultivation due to low organic matter content and low fertility. This land is highly susceptible to wind erosion, and a permanent vegetative cover is necessary to prevent soil blowing.

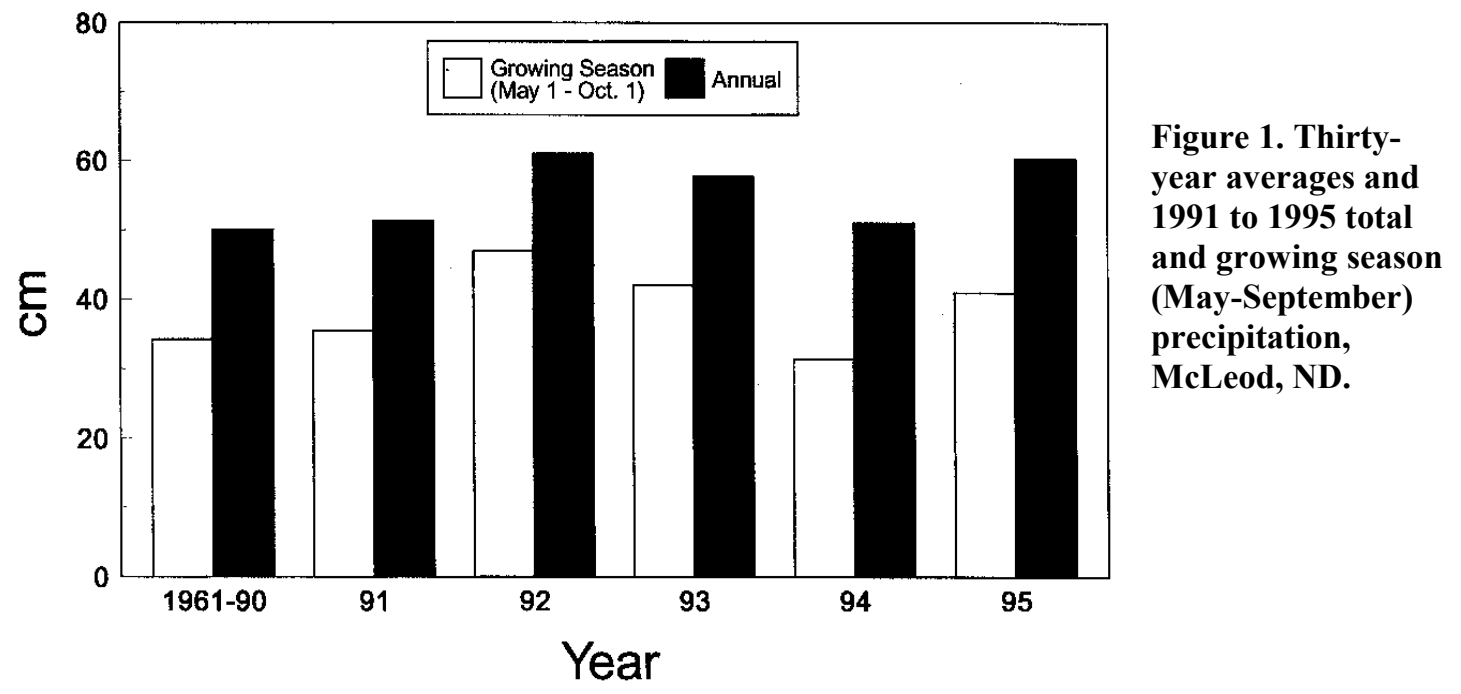

Page 3 of 9 
The study consisted of seven defoliation treatments applied to leafy spurge in 3- by 6-m plots. Each treatment was replicated three times in a randomized complete block design. Defoliation treatments were designed to coincide with phenological stages of leafy spurge growth and to simulate grazing by Angora goats. Defoliation treatments were no treatment; vegetative stage (May 15); flowering stage (June 20); mature stage (July 25); regrowth stage (September 1); once each at vegetative and regrowth stages; and once each at flowering and regrowth stages. Treatments were applied annually for 4 years. Defoliation simulated goat grazing by hand-stripping the leaves and removing the top $5 \mathrm{~cm}$ of each leafy spurge stem in study plots.

Vegetative measurements were taken in areas of study plots reserved from the present year's treatment. Density, cover, and herbaceous yield were estimated from four $0.1-\mathrm{m}^{2}$ Daubenmire quadrats (Cook and Stubbendieck 1986). Foliar cover was visually estimated and separated into leafy spurge and grass components. Herbaceous yield was determined by clipping, drying (60 C), and separating into categories of leafy spurge, Kentucky bluegrass (Poa pratensis L.), warm-season grasses, and total grasses.

The influence of defoliation date and frequency on leafy spurge and grass components was assessed among and across the years of 1991 and 1995 using the general factorial analysis of variance (ANOVA) procedure of SPSS (SPSS 1994) for a randomized complete block design. Tests were considered significant at $\mathrm{P}<0.05$. Treatment means were separated using Tukey's h test $(\mathrm{P}<0.05)$ when differences were observed.

\section{Results and Discussion}

Simulated defoliation of leafy spurge reduced leafy spurge populations and decreased growth, especially when defoliated twice per year. In 1991, total leafy spurge densities were similar $(\mathrm{P}>0.05)$ among treatments (Figure 2$)$. Total leafy spurge densities increased $(\mathrm{P}<0.05)$ in nontreated plots and decreased $(\mathrm{P}<0.05)$ in both twice-defoliated annual treatments over the study period. Single annual defoliations did not significantly affect leafy spurge populations after 4 years.

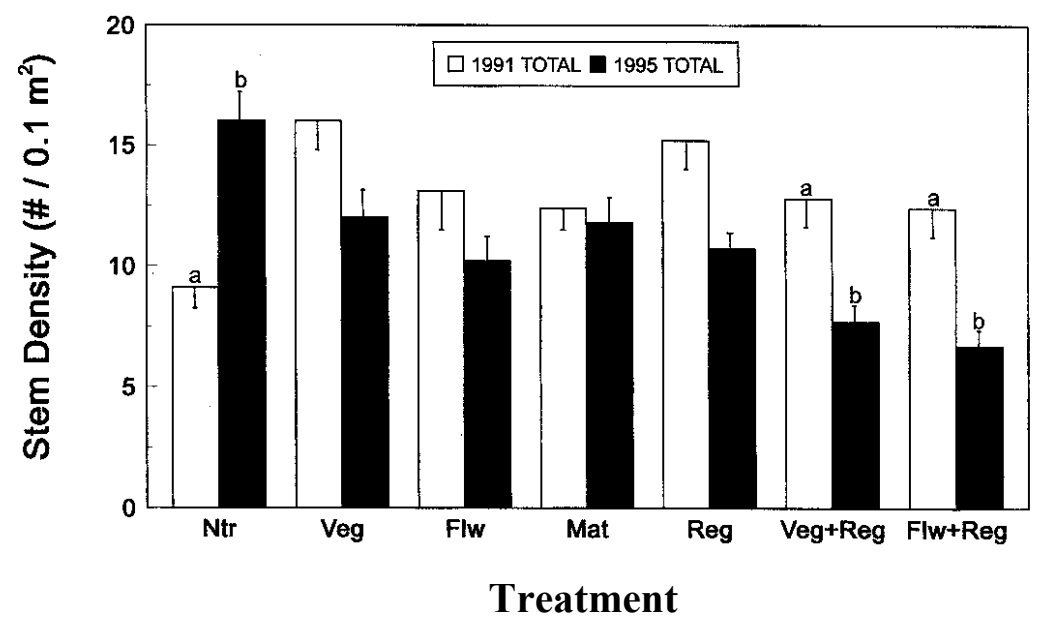

Figure 2. Total leafy spurge densities in nontreated (Ntr), vegetative (Veg), flowering (Flw), mature (Mat), regrowth (Reg), vegetative and regrowth (Veg + Reg), and flowering and regrowth (Flw + Reg) defoliation treatments. Standard error bars within treatments having a different letter differ $(P<0.05)$ according to Tukey's $h$ test. 
The recommended management for control of leafy spurge with sheep or goats is intense and continuous grazing of infested sites beginning as early in the growing season as possible (Bowes and Thomas 1978; Derscheid et al. 1985; Lym et al. 1997). In this study, we simulated the effects of various dates and frequencies of herded goat grazing on leafy spurge-infested rangeland with mixed results. Single defoliations at all growth stages did not reduce leafy spurge stem densities after 4 years. Twice-defoliated treatments, with the first defoliation prior to flowering and the second at regrowth, reduced total leafy spurge stem densities an average of 55\% over nontreated controls. In contrast, intense and continuous grazing by sheep or goats has reduced stem densities over $90 \%$ in three to four years (Bowes and Thomas 1978; Lym. et al. 1997; Sedivec et al. 1995).

Stem density of leafy spurge has been reported to influence cattle use of infested areas. Leafy spurge densities exceeding $100 \mathrm{stems} / \mathrm{m}^{2}$ decreased cattle use of infested sites and intensified grazing use of associated non-infested sites (Lym and Kirby 1987). Nondefoliated plots averaged $160 \mathrm{stems} / \mathrm{m}^{2}$ by 1995 , while single defoliation treatments all exceeded $100 \mathrm{stems} / \mathrm{m}^{2}$. Despite the increased grass yield on single defoliation treatments, cattle use would likely be limited due to the high density of leafy spurge stems. In contrast, twice-defoliated treatments averaged approximately $70 \mathrm{stems} / \mathrm{m}^{2}$. Leafy spurge at this density would be less likely to deter cattle from their normal foraging activities.

As with density, foliar covers of leafy spurge and graminoids were similar $(\mathrm{P}>0.05)$ among treatments in 1991 (Figure 3). From 1991 to 1995, leafy spurge cover increased (P $<0.05)$ in the nontreated, vegetative, and regrowth stage defoliation treatments. This is

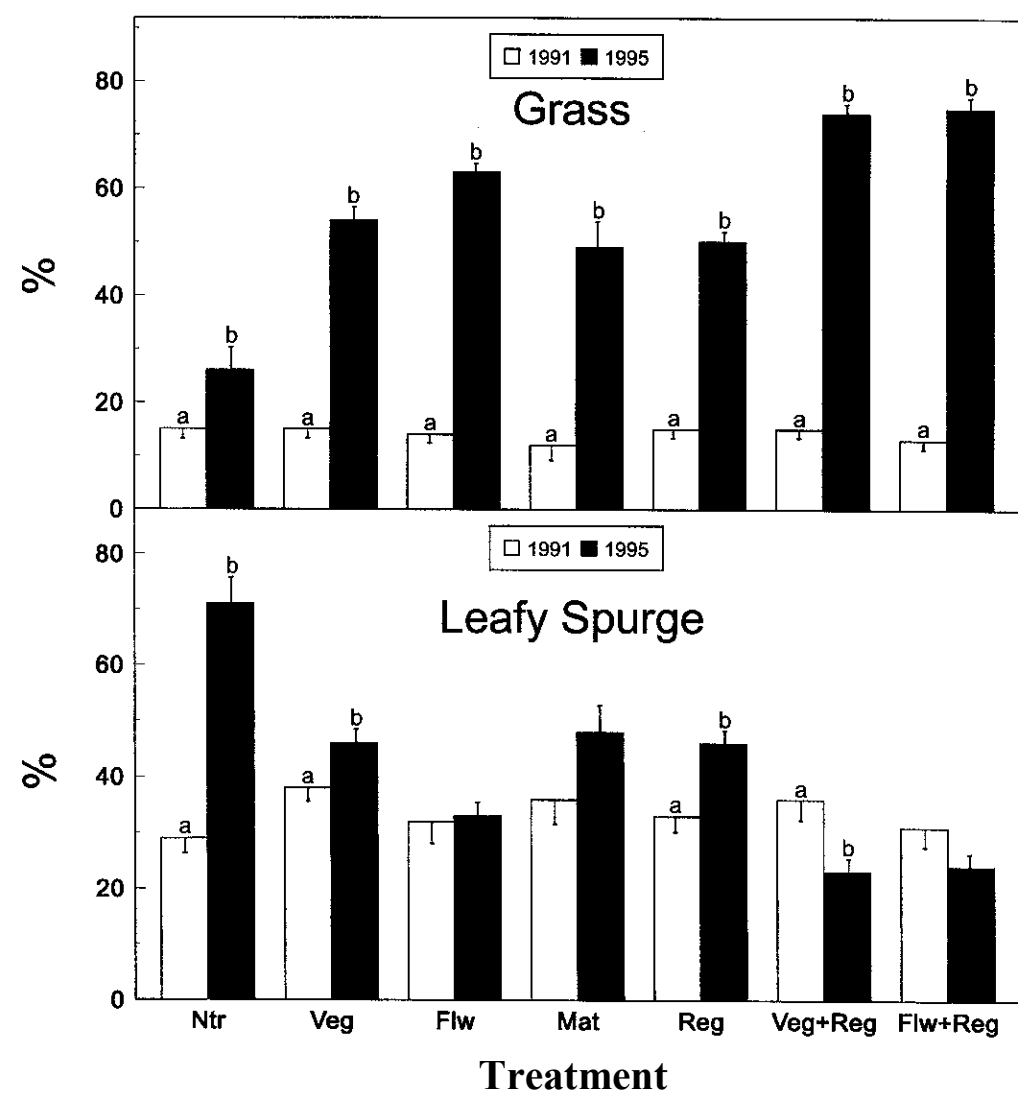

Figure 3. Grass and leafy spurge foliar cover in nontreated (Ntr), vegetative (Veg), flowering (Flw), mature (Mat), regrowth (Reg), vegetative and regrowth (Veg + Reg), and flowering and regrowth (Flw + Reg) defoliation treatments. Standard error bars within treatments having a different letter differ $(\mathrm{P}<0.05)$ according to Tukey's h test. 
probably a reflection of the good growing conditions over the study period, which favored the increased dominance and expansion of leafy spurge in rangeland plant communities (Figure 1). Decreases in leafy spurge foliar cover were estimated on both twice-defoliated treatments, although only the vegetative and regrowth defoliation treatment was significant $(\mathrm{P}<0.05)$.

Grass foliar cover increased $(\mathrm{P}<0.05)$ between 1991 and 1995 on all treatments (Figure 3), reflecting the good growing conditions throughout the study. Foliar cover doubled in nontreated plots and increased over fourfold on the defoliation treatments.

Herbaceous yields were similar among treatments in 1991 (Table 1). No difference (P $>0.05$ ) among treatments occurred in any grass category except total grass and leafy spurge yields. Total herbaceous yields were not different $(\mathrm{P}>0.05)$ among defoliation treatments at the initiation of the study.

Following 5 year of annual defoliation, Kentucky bluegrass and total grass yields were higher in all defoliation treatments compared to the nontreated plots (Table 1). Kentucky bluegrass and total grass yields were greater $(\mathrm{P}<0.05)$ in the flowering and both twice-defoliated treatments when compared to the nontreated plots. Conversely, leafy spurge yield was greater $(\mathrm{P}<0.05)$ in the nontreated plots when compared to all defoliated treatments except the vegetative stage treatment. Total yield was not different $(\mathrm{P}>$ 0.05 ) among treatments in 1995; however, leafy spurge comprised $65 \%$ of the total herbaceous yield in nontreated. plots and averaged less than $30 \%$ of yields in defoliated treatments.

Between 1991 and 1995, Kentucky bluegrass and total grass yields increased ( $\mathrm{P}<$ 0.05 ) in all defoliation treatments, but not in the nontreated plots (Table 1). Leafy spurge yield increased $(\mathrm{P}<0.05)$ in nontreated plots and decreased $(\mathrm{P}<0.05)$ in flowering stage and both twice-defoliated treatments. Total herbaceous yield, mainly leafy spurge, increased $(\mathrm{P}<0.05)$ in nontreated plots, while increases in herbaceous yield in vegetative and regrowth treatments were mainly contributed by Kentucky bluegrass. Total herbaceous yields in twice-defoliated treatments did not change because of the decreased leafy spurge yield.

Grass production increased in all defoliation treatments by 1995 . However, because of the high density and cover of leafy spurge in single defoliation treatments, cattle would avoid these areas and not utilize this increased forage. Grass production increased an average of $185 \%$ between 1991 and 1995 on twice-defoliated treatments. Since leafy spurge stem density did not exceed $100 \mathrm{stems} / \mathrm{m}^{2}$, normal cattle foraging activities would be expected to occur on this increased forage supply (Lym and Kirby 1987). Therefore, following several years of multiple defoliation, there would be potential for increases in stocking rate and cattle production per unit area. Considering average stocking rates for rangeland in this area, and similar forage yields in treated leafy spurge infestations, stocking rates would increase by 2.5 animal-unit (cow-calf pairs) months per hectare of treated leafy spurge. 
Table 1. Effect of repeated simulated defoliation treatments on herbaceous yield ( $\overline{\mathbf{x}}$ and SE) of leafy spurge-infested rangeland.

\begin{tabular}{|c|c|c|c|c|c|c|c|}
\hline \multirow{2}{*}{$\begin{array}{c}\text { Herbaceous } \\
\text { category }\end{array}$} & \multicolumn{7}{|c|}{ Defoliation treatments $^{\mathrm{a}}$} \\
\hline & Ntr & Veg & Flw & Mat & Reg & Veg + Reg & Flw + Reg \\
\hline & \multicolumn{7}{|c|}{ 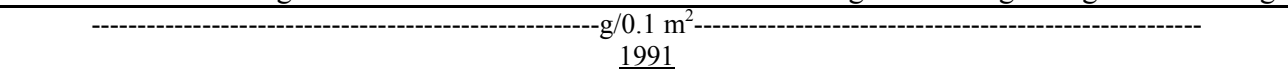 } \\
\hline $\begin{array}{l}\text { Kentucky blue- } \\
\text { grass }\end{array}$ & $6.5(0.8)$ & $7.3(0.7) \mathrm{x}^{\mathrm{b}}$ & $6.8(0.9) \mathrm{x}$ & $7.2(0.7) \times$ & $6.7(0.6) x$ & $8.4(0.6) x$ & $6.8(0.4) x$ \\
\hline $\begin{array}{l}\text { Warm-season } \\
\text { grasses }\end{array}$ & $0.7(0.3)$ & $0.5(0.3)$ & $0.1(0.1) \mathrm{x}$ & $2.4(14)$ & $1.0(0.4)$ & $0.5(0.3)$ & $0.2(0.1) \mathrm{x}$ \\
\hline Total grass & $9.7(0.7) a b^{c}$ & $9.5(0.6) \mathrm{abx}$ & $10.3(0.7) b c x$ & $11.4(1.7) b c x$ & $9.6(0.6) a b x$ & $14.0(0.8) \mathrm{cx}$ & $8.9(0.5)$ ax \\
\hline Leafy spurge & $9.8(1.3) \mathrm{x}$ & $14.7(1.5)$ & $15.2(2.1) \mathrm{x}$ & $12.0(1.5)$ & $10.6(1.2)$ & $12.5(1.3) \mathrm{x}$ & $13.4(2.0) \mathrm{x}$ \\
\hline $\begin{array}{l}\text { Total } \\
\text { herbaceous }\end{array}$ & $19.5(1.6) \mathrm{x}$ & $24.3(1.5) \mathrm{x}$ & $25.5(2.1)$ & $23.4(3.0)$ & $20.2(1.1) \mathrm{x}$ & $26.5(1.3)$ & $23.3(2.0)$ \\
\hline & \multicolumn{7}{|c|}{$\underline{1995}$} \\
\hline $\begin{array}{l}\text { Kentucky blue- } \\
\text { grass }\end{array}$ & $8.2(0.6) \mathrm{a}$ & 14.1 (1.5) aby & $15.4(0.8)$ by & 13.8 (1.1) aby & 11.7 (1.4) aby & $16.0(1.6)$ by & 14.5 (1.4) by \\
\hline $\begin{array}{l}\text { Warm-season } \\
\text { grasses }\end{array}$ & $0.6(0.2) \mathrm{a}$ & $1.3(0.6) \mathrm{ab}$ & 2.4 (0.6) aby & $1.6(0.6) \mathrm{ab}$ & $2.3(1.2) \mathrm{ab}$ & $1.8(0.8) \mathrm{ab}$ & $5.6(2.0)$ by \\
\hline Total grass & $10.2(0.8) \mathrm{a}$ & 18.0 (2.0) aby & $20.0(1.2)$ by & 18.1 (1.8) aby & 15.4 (2.7) aby & $19.9(1.8)$ by & $22.7(0.9)$ by \\
\hline Leafy spurge & $20.4(3.5)$ cy & $15.7(1.8) \mathrm{bc}$ & $3.8(1.0)$ ay & $9.5(1.6) \mathrm{ab}$ & $9.8(1.0) \mathrm{ab}$ & $5.5(0.7)$ ay & $3.5(0.5)$ ay \\
\hline $\begin{array}{l}\text { Total } \\
\text { herbaceous }\end{array}$ & $30.6(3.7) \mathrm{y}$ & $33.6(2.4) \mathrm{y}$ & $25.8(1.4)$ & $27.6(2.3)$ & $26.8(2.7) \mathrm{y}$ & $25.6(2.0)$ & $26.5(11)$ \\
\hline
\end{tabular}

Artificial defoliation, simulating a herded goat flock, suggests that a minimum of two grazings each growing season would be required to effectively control leafy spurge in rangeland. Single defoliations, regardless of timing, did not produce plant community responses favorable for cattle production from leafy spurge-infested rangeland. Two defoliations, the first prior to flowering followed by a second during fall regrowth, reduced stem density and foliar cover of leafy spurge below levels $\left(<100 \mathrm{stems} / \mathrm{m}^{2}\right)$ suggested as a deterrent to cattle grazing. Reduced competition from leafy spurge also resulted in significant increases in grass production, which should translate into more grazable forage, higher stocking rates, and greater cattle production per unit area.

\section{Literature cited}

Bangsund, D. A., J. A. Leitch, and F L. Leistritz. 1996. Economic Analysis of Herbicide Control of Leafy Spurge in Rangeland. Fargo, ND: North Dakota State University Agricultural Economic Report No. 342-S. $15 \mathrm{p}$.

Bowes, G. G. and A. G. Thomas. 1978. Longevity of leafy spurge seeds in the soil following various control programs. J. Range Manage. 31:137-140.

Cook, C. W. and J. Stubbendieck. 1986. Range Research: Basic Problems and Techniques. Denver, CO: Society for Range Management. $317 \mathrm{p}$.

Derscheid, L. A., L. J. Wrage, and W. E. Arnold. 1985. Cultural control of leafy spurge. In A. K. Watson, ed. Leafy Spurge. Monograph Series. Champaign, IL: Weed Science Society of America. pp. 57-64. 
Dunn, P. H. 1979. The distribution of leafy spurge and other Euphorbia spp. in the United States. Weed Sci. 27:509-516.

Hanson, T., D. Kirby, C. Sieg, and L. Potts. 1994. Botanical and nutritive composition of Angora goat diets grazing leafy spurge infested rangeland. In Abstracts of the 47th Annual Meeting. Colorado Springs, CO: Society for Range Management. $72 \mathrm{p}$.

Helgeson, E. A. and J. H. Longwell. 1942. Control of leafy spurge by sheep. N.D. Agric. Exp. Stn. Bull. 4:10-12.

Johnson, A. and R. W. Peake. 1960. Effect of selective grazing by sheep on the control of leafy spurge (Euphorbia esula L.) J. Range Manage. 13:192-195.

Kingsbury, J. M. 1964. Poisonous Plants of the United States and Canada. Englewood Cliffs, NJ: Prentice-Hall. 626 p.

Kronberg, S. L., W. C. Lynch, C. D. Cheney, and J. W. Walker. 1995. Potential aversive compounds in leafy spurge for ruminants and rats. J. Chem. Ecol. 21:1387-1399.

Kronberg, S. L., R. B. Muntifering, E. L. Ayers, and C. B. Marlow. 1993. Cattle avoidance of leafy spurge: A case of conditioned aversion. J. Range Manage. 46:364-366.

Lacey, C. A., R. W. Knott, and P. L. Fay. 1984. Ranchers control leafy spurge. Rangelands 6:202-204.

Leistritz, F. L., F. Thompson, and J. A. Leitch. 1992. Economic impact of leafy spurge (Euphorbia esula) in North Dakota. Weed Sci. 40:275-280.

Lym, R. G. and D. R. Kirby. 1987. Cattle foraging behavior in leafy spurge (Euphorbia esula L.) infested rangeland. Weed Technol. 1:314-318.

Lym, R. G. and C. G. Messersmith. 1985a. Leafy spurge control with herbicides in North Dakota: 20 year summary. J. Range Manage. 38:149-154.

Lym, R. G. and C. G. Messersmith. 1985b. Leafy spurge control and improved forage production with herbicides. J. Range Manage. 38:386-391.

Lym, R. G. and C. G. Messersmith. 1990. Cost-effective long-term leafy spurge (Euphorbia esula) control with herbicides. Weed Technol. 4:635-641.

Lym, R. G. and K. D. Moxness. 1989. Absorption, translocation, and metabolism of picloram and 2,4-D in leafy spurge (Euphorbia esula). Weed Sci. 37:498-502.

Lym, R. G., K. Sedivec, and D. R. Kirby. 1997. Leafy spurge control with angora goats and herbicides. J. Range Manage. 50:123-128.

Messersmith, C. G., R. G. Lym, and D. S. Galitz. 1985. Biology of leafy spurge. In A. K. Watson, ed. Leafy Spurge. Monograph Series. Champaign, IL: Weed Science Society of America. pp. 42-56.

Muller, B., R. K. Fay, and M. K. Petersen. 1990. Feeding leafy spurge hay to cattle. Proc. West. Soc. Weed Sci. 43:31-35.

North Dakota Department of Agriculture. 1991. Weed Control Survey by County. Bismarck, ND: North Dakota Department of Agriculture. 5 p.

Raju, M.V. S. 1985. Morphology and anatomy of leafy spurge. In A. K. Watson, ed. Leafy Spurge. Monograph Series. Champaign, IL: Weed Science Society of America. pp. 26-41.

Sedivec, K. K., W. T. Barker, and C. W. Prosser. 1995. Intensive grazing of angora goats on leafy spurge infested rangeland. In Proceedings of the Leafy Spurge Symposium. Fargo, ND: North Dakota State University. pp. 34-36.

Seiler, G. J. and W. T. Barker. 1985. Vascular flora of Ransom, Richland, and Sargent counties, North Dakota. Prairie Nat. 17:193-240.

Selleck, G. W., R. T. Coupland, and C. Frankton. 1962. Leafy spurge in Saskatchewan. Ecol. Monogr. 32:1-29.

Page 8 of 9 
SPSS, Inc. 1994. SPSS Advanced Statistics. Version 6.1. Chicago, IL: SPSS. 606 p.

Thompson, F., F. L. Leistritz, and J. A. Leitch. 1990. Economic Impact of Leafy Spurge in North Dakota. Fargo, ND: North Dakota State University Agricultural Economic Report No. 257. 23 p.

Walker, J. W, S. L. Kronberg, S. L. Al-Rowaily, and N. E. West. 1994. Comparison of sheep and goat preferences for leafy spurge. J. Range Manage. 47:429-434.

Williams, K. E., J. R. Lacey, and B. E. Olson. 1996. Economic feasibility of grazing sheep on leafy spurge infested rangelands in Montana. J. Range Manage. 49:372-374. 